mica dos tratamentos. Constatou-se que a antecipação da irrigação aumentou a produção de massa seca da parte aérea e a absorção de nutrientes pelas plantas. A calagem aumenta a produtividade de arroz irrigado. A época de início de irrigação aos 15 ou aos 35 dias após a emergência das plântulas não influencia a produtividade de arroz irrigado e o tratamento com $300 \mathrm{~kg}^{-\mathrm{ha}^{-1}}$ de calcário PRNT $91,2 \%$ apresentou o melhor retorno econômico, considerando apenas uma safra.

Palavras-chave: acidez, calcário, arroz irrigado, sementes e componentes do rendimento.

It is already known that the correction of soil acidity occurs naturally from 4 to 6 weeks after flooding. However, flooding by itself cannot substitute liming, since the so-called process of "self-liming" occurs near the end of the rice vegetative. On the other hand, a positive correlation between flooding and liming for rice is observed, in which the $\mathrm{pH}$ is ussualy adequate earlier than "self-liming". This experiment was conducted with the following objectives: (1) to evaluate the influence of acidity correction in flooded rice; (2) to estimate liming response to a delay in flooding and; (3) to estimate the economical viability of different liming procedures. Two experiments were conducted at the experimental area of the Department of Plant production with two different times of flooding ( 15 and 35 days after shooting), in Albaqualf soil. A completely randomized block design was used with four replications. The treatments (1) no lime, (2) 300 $\mathrm{kg} \cdot \mathrm{ha}^{-1}$ of class D lime, one day before crop sowing, (3) $1.6 \mathrm{t} . \mathrm{ha}^{-1}$ of class $\mathrm{C}$ lime, one day before crop sowing, (4) $1.6 \mathrm{t} . \mathrm{ha}^{-1}$ of class $\mathrm{C}$ lime, 30 days before crop sowing, (5) 3.2t.ha h $^{-1}$ of class $\mathrm{C}$ lime, one day before crop sowing and (6) 3.2 t. ha $^{-1}$ of class C lime 30 days before crop sowing. Chemical characteristics of the soil before and after cropping, productivity, dry matter production and nutrient absorption, grain yield components, physiological and physical quality of seeds and economical viability of the treatments were evaluated. Results demonstrated that anticipation of flooding increased the production of dry matter and the absorption of nutrients by the plants. Liming increases productivity in rice. Starting flooding 15 or 35 days after emergency does not influence crop productivity. The use of $300 \mathrm{~kg} \cdot \mathrm{ha}^{-1}$ of class D lime produces the best crop response in a single growing season.

Key words: acidity, lime, flooded rice, seeds and grain yeld components.

\title{
CONFORMAÇÃO DA PAISAGEM, UMIDADE E GÊNESE DE SOLOS DESENVOLVIDOS SOBRE O MEMBRO ALEMOA DA FORMAÇÃO SANTA MARIA ${ }^{1}$
}

\section{SOIL LANDSCAPE, MOISTURE AND GENESIS OF SOIL DEVELOPED FROM THE ALEMOA MEMBER OF SANTA MARIA FORMATION}

\author{
Autor: Alberto Vasconcellos Inda Junior ${ }^{2}$ \\ Comissão de Avaliação: Antonio Carlos de Azevedo ${ }^{3}$ \\ Egon Klamt ${ }^{4}$ \\ José Miguel Reichert ${ }^{5}$
}

A unidade de bacia é uma pequena bacia de drenagem, tomada como célula básica onde os proces- sos pedológicos, impulsionados pelo movimento da água, são condicionados pelas formas de relevo. $\mathrm{O}$

\footnotetext{
${ }^{1}$ Dissertação de Mestrado apresentada pelo primeiro autor, em 30.04.97, ao Curso de Pós-graduação em Agronomia, Centro de Ciências Rurais (CCR), Universidade Federal de Santa Maria (UFSM), para a obtenção do grau de Mestre em Agronomia

${ }^{2}$ Engenheiro Agrônomo. Curso de Pós-graduação em Agronomia, CCR, UFSM. 97119-905, Santa Maria, RS.

${ }^{3}$ Engenheiro Agrônomo, Professor Assistente, Departamento de Solos, CCR, UFSM.

${ }^{4}$ Engenheiro Agrônomo, Professor Visitante, Departamento de Solos, CCR, UFSM.

$5_{\text {Engenheiro Agrônomo, PhD, Professor Titular, Departamento de Solos, CCR, UFSM }}$ Recebido para publicasio em 30.06.97. Aprovado em 16.07.97.
} 
objetivo do trabalho foi caracterizar o solo em uma unidade de bacia que não sofreu intervenção de atividades humanas há pelo menos trinta anos. $\mathrm{O}$ solo nessa área é desenvolvido de rochas sedimentares da formação geológica Santa Maria. Aspectos morfológicos, químicos, físicos, mineralógicos e hídricos foram analisados no sentido de relacioná-los com a distribuição do conteúdo de água em função das formas dos declives. Para tanto, foram locados quatro transetos em três declives (um côncavo-côncavo, um convexolinear, um convexo-convexo) no campus da UFSM. Seis a nove pontos foram locados em cada transeto, totalizando 29 pontos, onde coletou-se amostras de solo até aproximadamente $2 \mathrm{~m}$ para as análises químicas e físicas, nos quais foi monitorado o conteúdo de água com sonda de nêutrons. No transeto côncavo, foram abertas duas trincheiras para descrição morfológica e coleta de amostras para caracterização da solução do solo e análises químicas, físicas, mineralógicas e sedimentológicas. Nas condições do estudo, observou-se maiores conteúdos de água e diferenciação dos horizontes do solo no declive côncavo em relaçăo aos convexos. No declive côncavo, o desenvolvimento do horizonte $\mathrm{E}$ se dá provavelmente pelo processo de ferrólise, associado à eluviação/iluviação, contrastando com os declives convexos, onde 0 horizonte E está em processo inicial de formação, provavelmente por eluviação/iluviação, não sendo possivel, com base nos dados obtidos, descartar a contribuiçăo da ferrólise. Também quimicamente o declive côncavo diferenciou-se dos convexos, apresentando maior concentração de $\mathrm{H}^{+}+\mathrm{Al}^{+3} \mathrm{e} \mathrm{Al}^{+3}$ em superfície, enquanto nos convexos a concentração desses elementos aumentou em profundidade. Entre os perfis analisados no transeto côncavo, um no terço inferior do declive, em posição mal drenada, e outro no terço superior, de melhor drenagem, foram observadas diferentes características morfológicas, químicas, físicas e sedimentológicas. O perfil inferior apresentou horizontes de coloração acinzentada e baixos valores de ferro total, indicando processo de redução do ferro, bem como sua saída do sistema. Já o perfil na posição mais elevada apresentou características que indicam uma maior atuação dos processos de intemperismo, associados à maior lixiviação, pela sua posição no declive. Estas variaçðes nas características do solo estão associadas às diferentes formas de declives e posiçð̃es de um mesmo declive onde se encontram e que condicionam a distribuição do conteúdo de água no solo.

Palavras-chave: gênese, solo-paisagem, umidade, ferrólise, feiçðes morfológicas.
The valley basin can be considered as the basic unit where geomorphic and pedologic process occur, triggered by water movement. The objective of this work was to characterize the soil in a valley basin which has not been disturbed by human activities during the past 30 years. The soil in this area is developed from sedimentary rocks of the Santa Maria geologic formation. Physical, chemical, morphological, mineralogical and hydric parameters were analysed and the results were related to water content variations on the slopes. To do so, four transepts were located on three slopes (one concaveconcave, one convex-linear, one convex-convex) in a valley basin at the UFSM campus. Six to nine points were located on each transept (total $=29$ points) and samples for chemical and physical analysis were colleted to the depth of approximately $2 \mathrm{~m}$, and water content was monitored with neutron probe. In addition, two profiles were exposed for morphological description, and samples were taken for soil solution characterization and chemical, physical, mineralogical, and sedimentological analysis. In the concave slope higher water content and greater horizon diferenciation were observed than in contrast to convex slopes. The E horizon development occurs probably by the ferrolysis process, associated with the eluviation/iluviation process in the concave slope; while in the convex slope eluviation/iluviation occurs, the $\mathrm{E}$ horizon is at an initial stage of formation, and no indication of ferrolysis was observed, although it can not be discarted based on the data obtained. In the concave slope greater levels of $\mathrm{H}^{+}+\mathrm{Al}^{+3}$ and $\mathrm{Al}^{+3}$ occur in surface horizons with an opposite behavior in the convex slopes, where the levels of these elements increase with depth. The profiles described in concave slope, one in the lover, poorly drained position, and other in the upper, well drained position, demonstrated distinct morphological, chemical, physical and sedimentalogical characteristics. The profile on the poorly drained position presented horizons with gray color and small content of total iron, indicating reduction and loss of iron from the system. The profile on the well drained position, presented characteristic that indicate a greater weathering than the poorly drained one, associated with greater leaching because of its position on the slope, All these features are due to or related to differeces in water content and water flux on each slope type and in each position on the slope.

Key words: genesis, soil landscape, moisture, ferrolysis, morphological features. 